\title{
IMPACT OF JOB SATISFACTION ON EMPLPOYEE TURNOVER INTENTION AT BANK AL-HABIB
}

\author{
Muhammad Yousuf ${ }^{1}$
}

\begin{abstract}
This study aims to examine the impact of job satisfaction on employee turnover intention in Bank Al Habib in Pakistan. This research is quantitative in nature and has utilized the double linear regression analysis and the data was collected through self-administrated structured questionnaire. A sample of 375 employees in the Bank Al Habib was selected randomly. The collected data was analyzed through partial least square technique using the Smart PLS software. The findings and results demonstrated that job satisfaction has a significant relationship with turnover intention. Five job-satisfaction dimensions as prescribed by the job descriptive index were employed to measure the job satisfaction variable, which include salary satisfaction, promotion satisfaction, work environment satisfaction, task satisfaction, and supervision satisfaction. The first-dimension salary satisfaction was found to have a significant relationship with turnover intention, which validates that if more salaries are offered to the employees, the job satisfaction level increases and turnover intention decreases. Similarly, the second dimension, promotion satisfaction was to also be found to have a significantly relationship with turnover intention which asserts that higher promotion and career development opportunities reduce the employee turnover intention. Correspondingly, the third variable, work environment satisfaction has a significant relationship with turnover intention which demonstrates that the better co-worker relationships and better physical work environment characteristics reduces employees' turnover intention. Likewise, the fourth and fifth variables task satisfaction and supervision satisfaction, respectively, also validate a significant relationship with job satisfaction and a significant relationship with turnover intention. The purpose of this study was to provide a valid framework to the managers and decision makers at bank Al-Habib which would help them devise appropriate
\end{abstract}

\footnotetext{
${ }^{1}$ Benazir School of Business, BBSU Karachi
} 
job motivational strategies to increase job satisfaction, reduce turnover intention and overall promote organizational productivity and efficiency.

Keywords: Job Satisfaction, Salary Satisfaction, Supervision Satisfaction, Task Satisfaction, Work Environment, Promotion Satisfaction, Turnover Intention.

\section{BACKGROUND AND INTRODUCTION}

Human resource is important asset for any organization; it helps an organization to achieve the goals. If the employees of an organization are committed, hard worker and they are satisfied with their job that can lead an organization to success. Human resource is one of the most dynamic assets in any organization for growth and development Due to change in technology and our social values most of the organization are facing challenges that are affecting on employees behavior and attitude but the HR have authorities to focus all challenges which are affecting employees satisfaction.(Jamshed, 2010).HR plays main role to increase productivity as well as cost afforded through train new staff and having to hire and give to the major role of the organization gaining strategies. It has become a big challenge for human resource managers to sustain employees for the long term because the high turnover of an employee in the organizations increased the cost of hiring a new workforce and this impact on productivity. The loyal employees are play key role for any organization to increased productivity and achieve their goals. Turnover intention develops gradually when workers are not satisfied with their work it is a major challenge during the current time. There are some organizations there are willing to reduce employee turnover intention and create a better work environment where employees are engaged and satisfied with their jobs and workplace. The main reason for employee turnover is that workers are not satisfied and not interested in their jobs and turnover intention reduces productivity and efficiency of the organization. The result of the increased level of turnover cause is like a on burden on the existing workplace, loss of social capital and low morale is one of indirect cost for any organization (Aleem M. , 2014). When employee feel undervalues in the current role and wants to change career paths, are also among the reasons for high turnover intention. Job satisfaction oppositely impact to turnover intention and this can cause a lower turnover growth in organizational productivity and performance (Ramesh, 2012). Turnover intention chances when employees find better opportunities in other organizations. In current situation turnover intention is a critical issue many organizations are detecting way to reduce employee turnover intention and to create work environment where 
employees are satisfied with their work. (Jeffrey, 2007) stated that if an employee of an organization is not satisfied with their job and organization don't have trust in their employees the employee's intention towards turnover will be greater and they may leave their job and job duration can be smaller Job satisfaction reflects an employee's feelings towards his work that can be seen from the employee's attitude towards work and everything in his work environment (Prinsa, 2016). Job satisfaction influenced by what employee for getting satisfied with their work. Job satisfaction and a high level of happiness of an employee can refers to high return for any organization (Ali, 2019).

Satisfaction and happiness play a vital role in any organization because when an employee is loyal to the company that helps the company to survive in various conditions that can help the company for achieving its goals effectively. A high employee turnover intention dangerous affects organizational performance (Khan, 2014).

The banking sector of Pakistan is playing very important role in the growth of economy. Today nearly $80 \%$ of assets are clasp by the private sector banks(Aftab, 2012). According to (Saeed, 2014) Banking sectors of Pakistan are more suffering high employee turnover. The causes of high employee turnover are due to abusive supervisor behavior, substandard working condition and lack of opportunities for growth and development. According to (Thomsan, 2010) there are so many challenges which are being faced in banking sectors, employee's turnover is the one of major issue in banking sector Pakistan. In Pakistan 35\% banks are facing employee turnover challenge due to this bank faced the issue of service quality, customer focus, customer attention and customers feedback that can only be provided when employee are talented and motivated.(Masood Hassan, 2019) Stated that multiple number of studies has been done and focused on turnover intention in different organization and it has found that lack of training and development and poor working environment encourages employee to switch their job.(Som, 2018) stated that employees of an organization are considered most valuable asset. The performance of any depends on attracting, retaining and motivating employees. Job stress and dissatisfaction is a major issue being faced in banking sector of Pakistan. This study limited in banking sectors and in this study locates that cause of employee turnover intention are a combination of factors such as dissatisfied, lack motivation and lake of interest could be a reason of dissatisfaction and research also aim to reduce employee turnover intention and create a more employee-oriented culture to help employee satisfaction and also aims to find out influences of job satisfaction and turnover intention. Through this research get to understand the relationship between job satisfaction and turnover intention within organization it will help 
to make policies that are inclined to reduce employee turnover intention. This research is conducted in bank Al Habib but result can be generalized to all banking sector of Pakistan. It will make easier the investigator to survey. Study may also advice to bank sectors it would facilitate in banking sector to grow and develop new strategies and reduce employee turnover.

\section{Industry Brief}

Banks are the biggest source of financial for any nation. Bank Al Habib is one of the important names in the banking sector of Pakistan and bank Al Habib played a vital role in meeting the banking and financial needs of Pakistan. Bank Al Habib has more than 835 branches and subbranches with more than 15000 employees. Bank Al Habib is planning to add more branches at the end of 2020. It included the banking capital market and investment banking industry. According to a report by Bank Al Habib in august 2020, the assets of the bank grew up by 1.36 trillion. Bank has wholesale branches in Bahrain and other countries. Bank Al Habib is the place of opportunities where your skill may help you to make your banking career.

Pakistan's Banking Industry Performance (2018-2019)

\begin{tabular}{|c|c|c|c|c|}
\hline BANK NAME & $\begin{array}{l}\text { RANK IN } \\
2019\end{array}$ & $\begin{array}{l}\text { GROWTH } \\
\text { RATE }\end{array}$ & $\begin{array}{l}\text { EARNING } \\
\text { PER } \\
\text { SHARE IN } \\
2019\end{array}$ & $\begin{array}{l}\text { EARNING } \\
\text { PER } \\
\text { SHARE IN } \\
2018\end{array}$ \\
\hline MCB & $1^{\mathrm{ST}}$ & $12.2 \%$ & RS 20.14 & RS 17.7 \\
\hline UBL & $2^{\mathrm{ND}}$ & $25 \%$ & RS 15.63 & RS 12.44 \\
\hline SCB & $3^{\text {RD }}$ & $43 \%$ & RS 4.14 & RS 2.90 \\
\hline NBP & $4^{\mathrm{TH}}$ & $8.45 \%$ & RS 7.43 & RS 9.41 \\
\hline HBL & $5^{\mathrm{TH}}$ & $24.5 \%$ & RS 10.45 & RS 8.22 \\
\hline Meezan Bank & $6^{\text {th }}$ & $70 \%$ & RS 6.97 & RS 11.84 \\
\hline ABL & $7^{\mathrm{TH}}$ & $9.5 \%$ & RS 12.32 & RS 11.25 \\
\hline Bank Alfalah & $8^{\mathrm{TH}}$ & $19 \%$ & RS 7.15 & RS 5.98 \\
\hline Bank Al Habib & $9^{\text {th }}$ & $32 \%$ & RS 10.05 & RS 7.57 \\
\hline $\begin{array}{l}\text { Bank of } \\
\text { Punjab }\end{array}$ & $10^{\text {th }}$ & $9 \%$ & RS 3.12 & RS 2.06 \\
\hline
\end{tabular}

\section{Research Questions}

1. Is there a relationship between employee job satisfaction and employees turnover intention in the banking sector in Pakistan?

2. Is there a significant inverse relationship between employee job satisfaction and turnover intention in the banking sector in Pakistan? 


\section{Objective of the Study}

1. To identify the association between job satisfaction on employee turnover intention.

\section{LITERATURE REVIEW}

A recent study conducted by (Swe, 2019) to find the influence of employee engagement on reducing employee turnover intention and increases/improves employee job satisfaction. The authors adopted a probability sampling technique and collected data from 36 employee respondents by random sampling. The study was conducted with a mixed-method approach with quantitative data for every question and qualitative data was collected through a semistructured interview where data were analyzed for statistical software and simple linear regression was applied to t-test data. And the result indicates the strong connection between employee engagement and job satisfaction as well as employee turnover intention of an employee in the organization.

\section{Salary Satisfaction}

In a recent study conducted by Hung (2018) on the moderating effect of salary satisfaction and working pressure on the organizational climate, organizational commitment to the turnover intention where the authors were issued 990 questionnaires, 771 valid questionnaires, and 221 invalid questionnaires and the response rate was $77.9 \%$ the result demonstrated that pay satisfaction directly affects the work pressure on organizational commitment and employee turnover intention. (Chin, The Influence of Job Satisfaction on Employee Turnover, 2018)studied the influence of job satisfaction on employee turnover intention in the manufacturing industry of Malaysia. Where the authors adopted the probability sampling technique and collected from 100 respondents through random sampling. The result illustrated that there is no significant relationship between the factor of salary for job satisfaction and employee turnover intention. According to (Nawaz, 2015) studied on the relationship between human resource development factors, career growth and turnover intention in different private universities of Pakistan. The authors adopted probability sampling techniques and collected data from 270 respondents through random sampling where data were analyzed by partial through PLS software was applied to test the data. the study illustrated that a negative effect of salary on employee turnover intention.

\section{Promotion Satisfaction}


Bibi (2017) studied the impact of payment and promotion opportunities on employee retention in education institute where the author's data collected from 220 faculty members working in the public sector in Pakistan and the authors was used PLS to analyze the data. The result found that promotional opportunities had an imperative relationship with employee retention. On the other hand, (Busari, 2016)studied analytical cognitive style moderation on promotional and turnover intention in the KPK Province of Pakistan where the data collected from 502 respondents to the entire province and the result demonstrated that a negative significant of promotion in turnover intention. Similarly, (Qingjuan, 2019) studied the impact of promotion justice on occupational health and turnover intention in China and the objective of the study is to explore the impact of promotion justice on employee's occupational health and turnover intention as well as its functioning mechanism and the result indicated that promotion justice influences employees and occupational health and turnover intention.

\section{Work Environment}

According to (Ramly, 2019) studied in the Mandiri Bank Indonesia and where the authors used quantitative research and the authors selected from 430 employees was randomly selected. The result found that the work environment has a positive and significant impact on job satisfaction. A recent study conducted by (Shang, 2018) studied in China the authors conducted from 778 respondents' nurses from seven hospitals were surveyed on work environment and turnover intention. The result demonstrated that the work environment was positively associated with higher work engagement and lower turnover intention.

\section{Supervisor Satisfaction:}

According to (Akhtar, 2020)studied on impacts of supervision on turnover intentions in a Manufacturing firm in Pakistan and the authors used quantitative research and 200 questionnaires were distributed and data was analyzed into smart PLS. The result illustrated that there is positive relationships between supervision and turnover intention. In this regard (Senevirathne, 2020) studied the relationship between co-worker's support, supervisor support, organizational support, and employee turnover intention of operational level employees in the apparel sector central province in Srilanka, and the data gathered through and questionnaire were analyzed using SPSS data analysis package. The result demonstrated that there was a negative relationship between supervision and employee turnover intention of the operational level of employees. On the other hand (Jumani, 2015) studied in the district Rawalpindi and 
Islamabad where the authors collected from 13764 respondents in the teachers of Islamabad and Rawalpindi through random sampling and t- test and linear regression analysis was used for the analysis of data. the result shows that there was a moderate relationship between supervision with turnover intention.

\section{Task Satisfaction}

According to (Garg, 2012) the purpose of the study to examine the determinant of job satisfaction on employee turnover in hotel. The data revealed that the choice of task and task performance has positive impact on employee turnover and data shows that there should balance in order to attract potential employee that affect task satisfaction that directly led to turnover. Similar study was conducted by (Huang, 2017)a questionnaire was developed to gather data in China, the sample of the study consisted of employees from different size, organization and industries and distributed 462 questionnaires among them. The result showed that task satisfaction has negative influence on turnover intention.

\section{THEORETICAL FRAMEWORK}

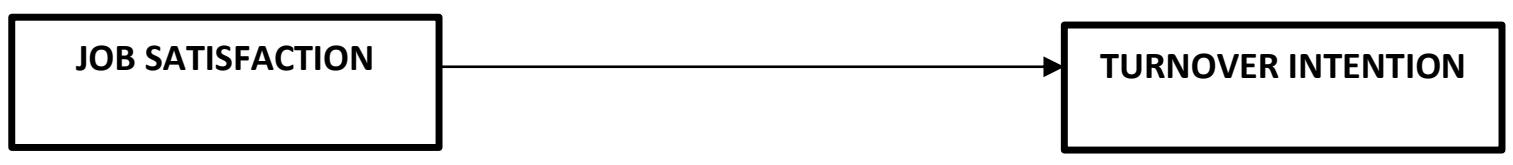

\section{RESEARCH METHODOLOGY}

\section{Research design:}

Our research type is quantitative research. This research is explanatory in nature as we are doing theory testing thus the research objective is to test the theory and hypothesis developed on the basis of the previous literature. The scope of the research is applied research as it will be applicable only in the business organizations in Pakistan. The method of research will be mono method as we are doing quantitative research only. The technique of the research will be secondary as we have taken data from the business organization in Pakistan through survey questionnaires. The approach will be deductive it will be from general to specific as data will be collected only from one organization in Pakistan. The time horizon is cross- sectional as the data will be gather from business organization (Bank Al-Habib) in Pakistan. The data collection 
approach is primary, and the type of research investigation is correlational as there is no interference. The study setting is based on the natural environment.

\section{Procedure:}

This study is a cross-sectional study and will use a quantitative approach through descriptive statistics to measure the multi-dimension of employee satisfaction and turnover intention.

\section{Population:}

Today, the bank Al Habib is fastest growing bank in Pakistan, it has over 835 plus branches and sub-branches in countries where more than 15,000 employees working in this bank.

\section{Sample and Sampling Methods:}

The data collection will be done through non-probability (convenience sampling). The questionnaires will be distributed to staff in all departments in Bank Al Habib through email and in-person visits and the sample size of this research is 375 and the confidence level is $95 \%$ and the margin of error is 5\% according to (Raosoft, Sample size calculator, 2020). The respondents will be given fifteen days to complete the survey. The respondents will also be briefed that the survey is used only for academic purposes.

\section{Instrument Selection:}

In this research, a structured questionnaire is used to obtain data and gather information regarding employee satisfaction in bank Al Habib. The survey questionnaire was adopted from previous similar studies of (Salleh R. , 2012), (Index, 2009) and it was to make sure that the survey is readable, consistent, clear, and feasible for respondents to answer.

\section{RESEARCH HYPOTHESIS}

$H 1$ = Salary and turnover intention have a significant relationship

H2 = Promotion, and turnover intention have a significant relationship

H3 = Work environment and Turnover intention have a insignificant relationship

H4 = Task satisfaction and Turnover intention have a significant relationship

H5 = Supervision and Turnover intention have a significant relationship

\section{DATA ANALYSIS}


Table 1: Respondent Profile

\begin{tabular}{|c|c|c|c|c|}
\hline Factors & Respondents & Category & Frequency & Percentage \% \\
\hline Gender & 375 & $\begin{array}{l}\text { Male } \\
\text { Female }\end{array}$ & $\begin{array}{l}375 \\
0\end{array}$ & $\begin{array}{l}\text { Male }=100 \\
\text { Female }=0\end{array}$ \\
\hline Age & 375 & $\begin{array}{l}18-25 \\
26-35 \\
35-45 \\
46-55 \\
56 \text { Above }\end{array}$ & $\begin{array}{l}57 \\
103 \\
143 \\
65 \\
7\end{array}$ & $\begin{array}{l}18-25=15.2 \\
26-35=27.5 \\
36-45=38.1 \\
46-55=17.3 \\
56 \text { Above }=1.9\end{array}$ \\
\hline Qualification & 375 & $\begin{array}{l}\text { Matric / O - level } \\
\text { Intermediate } \\
\mathrm{A}-\text { level } \\
\text { Bachelors } \\
\text { Masters } \\
\text { Doctorate }(\mathrm{PhD})\end{array}$ & $\begin{array}{l}0 \\
0 \\
166 \\
201 \\
8\end{array}$ & $\begin{array}{l}\text { Matric } / \mathrm{O}-\text { level }= \\
0 \text { Intermediate } / \mathrm{A}- \\
\text { level }=0 \\
\text { Bachelors }=44.3 \\
\text { Masters }=53.6 \\
\text { Doctorate }(\mathrm{PhD})=2.1\end{array}$ \\
\hline Experience & 375 & $\begin{array}{l}\text { Less than } 1 \text { year } \\
1 \text { year to } 4 \text { years } \\
5 \text { years to } 10 \text { years } \\
11 \text { years to } 15 \text { years } \\
16 \text { years to } 20 \text { years } \\
21 \text { years or above }\end{array}$ & $\begin{array}{l}33 \\
61 \\
121 \\
95 \\
55 \\
10\end{array}$ & $\begin{array}{l}\text { Less than } 1 \\
\text { year }=8.81 \text { year } \\
\text { to } 4 \text { years }=16.3 \\
5 \text { years to } 10 \text { years }=32.3 \\
11 \text { years to } 15 \text { years }=25.3 \\
16 \text { years to } 20 \\
\text { years }=14.321 \\
\text { years to above }=2.7\end{array}$ \\
\hline
\end{tabular}

As per the table 1, it has been confirmed that from the 375 participants 375 are male and there is no female and also it has confirmed that from the 375 participants 57 are between the ages of 18 to 25,103 are between the ages of 26 to 35,143 are between the ages of 35 to 45 , and 65 are between the ages of 46-55. Moreover, 7 are above 56.and also the table shows that 166 have done Bachelors, 201 have done Masters and 8 done have doctorate.

Table 2: Descriptive Analysis 


\begin{tabular}{|c|c|c|c|c|c|}
\hline No. & Items & Questions & $\begin{array}{l}\begin{array}{l}\text { Respon } \\
\text { dents } \\
(\mathrm{N})\end{array} \\
\end{array}$ & Mean & $\begin{array}{l}\text { Standard } \\
\text { Deviation }\end{array}$ \\
\hline \multicolumn{6}{|c|}{ Variable: Job Satisfaction (IV) - Salary Satisfaction } \\
\hline Item \#1 & SS1 & Salary paid & 375 & 4.21 & .941 \\
\hline Item \#2 & SS2 & Salary and workload & 375 & 4.21 & .990 \\
\hline Item \#3 & SS3 & Salary and benefits & 375 & 4.25 & .932 \\
\hline \multicolumn{6}{|c|}{ Variable: Job Satisfaction (IV) - Job Promotion } \\
\hline Item \#1 & $\begin{array}{l}\text { Job Promotion } \\
\text { JP1 }\end{array}$ & $\begin{array}{l}\text { Promotion } \\
\text { are given }\end{array}$ & 375 & 4.20 & .880 \\
\hline Item \#2 & JP2 & Chances of advancement & 375 & 4.22 & .995 \\
\hline Item \#3 & JP3 & $\begin{array}{ll}\text { Training } & \text { and } \\
\text { development } & \end{array}$ & 375 & 4.26 & .935 \\
\hline \multicolumn{6}{|c|}{ Variable: Job Satisfaction (IV) - Work Environment } \\
\hline Item \#1 & $\begin{array}{l}\text { Work } \\
\text { Environment } \\
\text { WE1 }\end{array}$ & $\begin{array}{l}\text { Pleasantness of the } \\
\text { working condition }\end{array}$ & 375 & 4.40 & .753 \\
\hline Item \#2 & WE2 & $\begin{array}{l}\text { Friendliness of my co- } \\
\text { workers }\end{array}$ & 375 & 4.41 & .789 \\
\hline Item \#3 & WE3 & $\begin{array}{l}\text { Physical working } \\
\text { condition }\end{array}$ & 375 & 4.46 & .776 \\
\hline \multicolumn{6}{|c|}{ Variable: Job Satisfaction (IV) - Task Satisfaction } \\
\hline Item \#1 & $\begin{array}{l}\text { Task } \\
\text { Satisfaction } \\
\text { TS1 }\end{array}$ & Recognition of the work & 375 & 4.23 & .906 \\
\hline Item \#2 & TS2 & Skills and qualification & 375 & 4.05 & 1.226 \\
\hline Item \#3 & TS3 & $\begin{array}{l}\text { Chance to develop new } \\
\text { ways }\end{array}$ & 375 & 4.28 & 1.044 \\
\hline \multicolumn{6}{|c|}{\begin{tabular}{|l|} 
Variable: Job Satisfaction (IV) - Supervision Satisfaction \\
\end{tabular}} \\
\hline Item \#1 & $\begin{array}{l}\text { Supervision } \\
\text { Satisfaction } \\
\text { SUS1 }\end{array}$ & Boss delegates work & 375 & 4.23 & .905 \\
\hline Item \#2 & SUS2 & $\begin{array}{l}\text { Boss take care of the } \\
\text { complaints }\end{array}$ & 375 & 4.17 & 1.079 \\
\hline Item \#3 & SUS3 & Hard problems & 375 & 4.13 & 1.205 \\
\hline \multicolumn{6}{|c|}{ Variable: Turnover Intention (DV) } \\
\hline Item \#1 & $\begin{array}{l}\text { Turnover } \\
\text { Intention TI1 }\end{array}$ & Leaving your job & 375 & 4.31 & 1.204 \\
\hline Item \#2 & TI2 & $\begin{array}{l}\text { Newspaper in search of } \\
\text { alternative job } \\
\text { opportunities }\end{array}$ & 375 & 3.96 & 1.443 \\
\hline
\end{tabular}




\begin{tabular}{|l|l|l|l|l|l|}
\hline Item \#3 & TI3 & $\begin{array}{l}\text { Better suit your personal } \\
\text { needs }\end{array}$ & 375 & 4.22 & 1.266 \\
\hline Item \#4 & TI4 & $\begin{array}{l}\text { Personal work-related } \\
\text { Goals }\end{array}$ & 375 & 4.39 & 1.010 \\
\hline Item \#5 & TI5 & $\begin{array}{l}\text { Alternative job } \\
\text { opportunities }\end{array}$ & 375 & 3.87 & 1.580 \\
\hline
\end{tabular}

As per the table 2, it has been confirmed that from the 375 participants and we find the Mean and standard deviation of all variables dependent and independent variable.

Table 3: Construct Reliability and Validity

\begin{tabular}{|l|l|l|l|l|}
\hline & $\begin{array}{l}\text { Cronbach's } \\
\text { Alpha }\end{array}$ & rho_A & $\begin{array}{l}\text { Composite } \\
\text { Reliability }\end{array}$ & $\begin{array}{l}\text { Average } \\
\text { Variance } \\
\text { Extracted } \\
\text { (AVE) }\end{array}$ \\
\hline Pay/Salary Satisfaction & 0.942 & 0.942 & 0.963 & 0.896 \\
\hline Promotion Satisfaction & 0.922 & 0.923 & 0.950 & 0.864 \\
\hline Supervisor Satisfaction & 0.909 & 0.914 & 0.943 & 0.846 \\
\hline Task Satisfaction & 0.895 & 0.900 & 0.935 & 0.827 \\
\hline Turnover Intention & 0.887 & 0.892 & 0.917 & 0.688 \\
\hline $\begin{array}{l}\text { Work Environment } \\
\text { Satisfaction }\end{array}$ & 0.906 & 0.906 & 0.941 & 0.842 \\
\hline
\end{tabular}

The accuracy of questionnaire results is indicated by reliability. For a similar target group, it will offer a comparable outcome at any stage the questioner reuses the questionnaire. It shows that the survey's internal accuracy and repeatability are strong. Maintaining a strategic distance towards unfairness in study is the primary indicator for unswerving consistency. It continues to be strengthened in this way by checking the pursuit procedure and investigation, as is achieved by using various analysis and review methods or various researchers. This often integrates the exploration's reliability and validity.

Using composite reliability, the reliability of the measurement instrument was assessed. All values were over the standard value usually used, i.e., 0.70. This is the agreed value set for reliability. The level of constancy between different variables could be used to estimate reliability. 
According to (Hair, 2006) the accepted reliability of the indicators must be above 0.70 , the values of all variables in the above table are above 0.7 , which indicates that the data is accurate and reliable.

\section{Average Variance Extracted (AVE)}

Average variance extracted is evaluated in order to check the convergent validity if the variance extracted value is greater than 0.5 termed as less effective for the study. The table clearly indicates that variance extracted values are above 0.5 of all the variables which shows questions of variables were perfect.

\section{Validity}

Three type of validity is testing firstly, discriminant validity is tested then construct validity and at last, convergent validity. Discriminant validity is checked with the help of FornellLarcker criterion. moreover, construct validity is checked with the help of factors loading however convergent validity is checked with the help of average variance extracted.

Table 4: Discriminant Validity:

\begin{tabular}{|c|c|c|c|c|c|c|}
\hline & $\begin{array}{c}\text { Pay/Salary } \\
\text { Satisfaction }\end{array}$ & $\begin{array}{c}\text { Promotion } \\
\text { Satisfaction }\end{array}$ & $\begin{array}{c}\text { Supervisor } \\
\text { Satisfaction }\end{array}$ & $\begin{array}{c}\text { Task } \\
\text { Satisfaction }\end{array}$ & $\begin{array}{c}\text { Turnover } \\
\text { Intention }\end{array}$ & $\begin{array}{c}\text { Work } \\
\text { Environment } \\
\text { Satisfaction }\end{array}$ \\
\hline $\begin{array}{c}\text { Pay/Salary } \\
\text { Satisfaction }\end{array}$ & $\mathbf{0 . 9 4 6}$ & & & & & \\
\hline $\begin{array}{c}\text { Promotion } \\
\text { Satisfaction }\end{array}$ & 0.845 & $\mathbf{0 . 9 3 0}$ & & & & \\
\hline $\begin{array}{c}\text { Supervisor } \\
\text { Satisfaction }\end{array}$ & 0.777 & 0.780 & $\mathbf{0 . 9 2 0}$ & & & \\
\hline $\begin{array}{c}\text { Task } \\
\text { Satisfaction }\end{array}$ & 0.830 & 0.833 & 0.837 & $\mathbf{0 . 9 0 9}$ & & \\
\hline $\begin{array}{c}\text { Turnover } \\
\text { Intention }\end{array}$ & 0.769 & 0.768 & 0.788 & 0.780 & $\mathbf{0 . 8 3 0}$ & \\
\hline $\begin{array}{c}\text { Work } \\
\text { Environment } \\
\text { Satisfaction }\end{array}$ & 0.688 & 0.711 & 0.646 & 0.694 & 0.587 & $\mathbf{0 . 9 1 7}$ \\
\hline
\end{tabular}

The concept of discriminant validity in introduced by (Fiske, 1959)Discriminant validity evaluations are actually non-related to ideas or measurement system that are not necessarily 
correlated with another test. (Henseler, 2016) through their debate on determining test validity, (Fornell, 1981) suggested the square of AVE of each variable can be used to determine the discriminant validity. Although there is no scale parameter for discriminant validity, a response less than 0.85 means that the measurements are likely to have discriminant validity. However, the findings of variables are greater than 0.85 , therefore, the table 4 shows that the questions are valid and the discriminant validity cannot be claimed among them.

Table 5: HTMT Heterotrait-Monotrait Ratio:

\begin{tabular}{|c|c|c|c|c|c|c|}
\hline & $\begin{array}{l}\text { Pay/Salary } \\
\text { Satisfaction }\end{array}$ & $\begin{array}{l}\text { Promotion } \\
\text { Satisfaction }\end{array}$ & $\begin{array}{l}\text { Supervisor } \\
\text { Satisfaction }\end{array}$ & $\begin{array}{c}\text { Task } \\
\text { Satisfaction }\end{array}$ & $\begin{array}{l}\text { Turnover } \\
\text { Intention }\end{array}$ & $\begin{array}{c}\text { Work } \\
\text { Environment } \\
\text { Satisfaction }\end{array}$ \\
\hline $\begin{array}{l}\text { Pay/Salary } \\
\text { Satisfaction }\end{array}$ & & & & & & \\
\hline $\begin{array}{l}\text { Promotion } \\
\text { Satisfaction }\end{array}$ & 0.847 & & & & & \\
\hline $\begin{array}{l}\text { Supervisor } \\
\text { Satisfaction }\end{array}$ & 0.840 & 0.852 & & & & \\
\hline $\begin{array}{c}\text { Task } \\
\text { Satisfaction }\end{array}$ & 0.843 & 0.856 & 0.823 & & & \\
\hline $\begin{array}{l}\text { Turnover } \\
\text { Intention }\end{array}$ & 0.839 & 0.845 & 0.810 & 0.868 & & \\
\hline $\begin{array}{c}\text { Work } \\
\text { Environment } \\
\text { Satisfaction }\end{array}$ & 0.745 & 0.778 & 0.714 & 0.769 & 0.655 & \\
\hline
\end{tabular}

It shows the construct of question with each other. The cut off value should be less than 0.9 or below 1 shows lack of discriminant validity whereas, above 0.85 and 0.9 indicates that two construct overlap strongly therefore the table 5 above reveals that HTMT of the constructs are less than 0.9 which indicates that discriminant validity is established and items are different and not correlated with each other.

The measurement of model is to study the reliability and validity of the instrument. The threshold value is 0.7 or higher according to (Henseler J. , 2010) and above table shows perfect reliability and validity in statement and indicators, in this result, all the factors of variables are above 0.8 which indicates the strong loading of all factors in the model. 


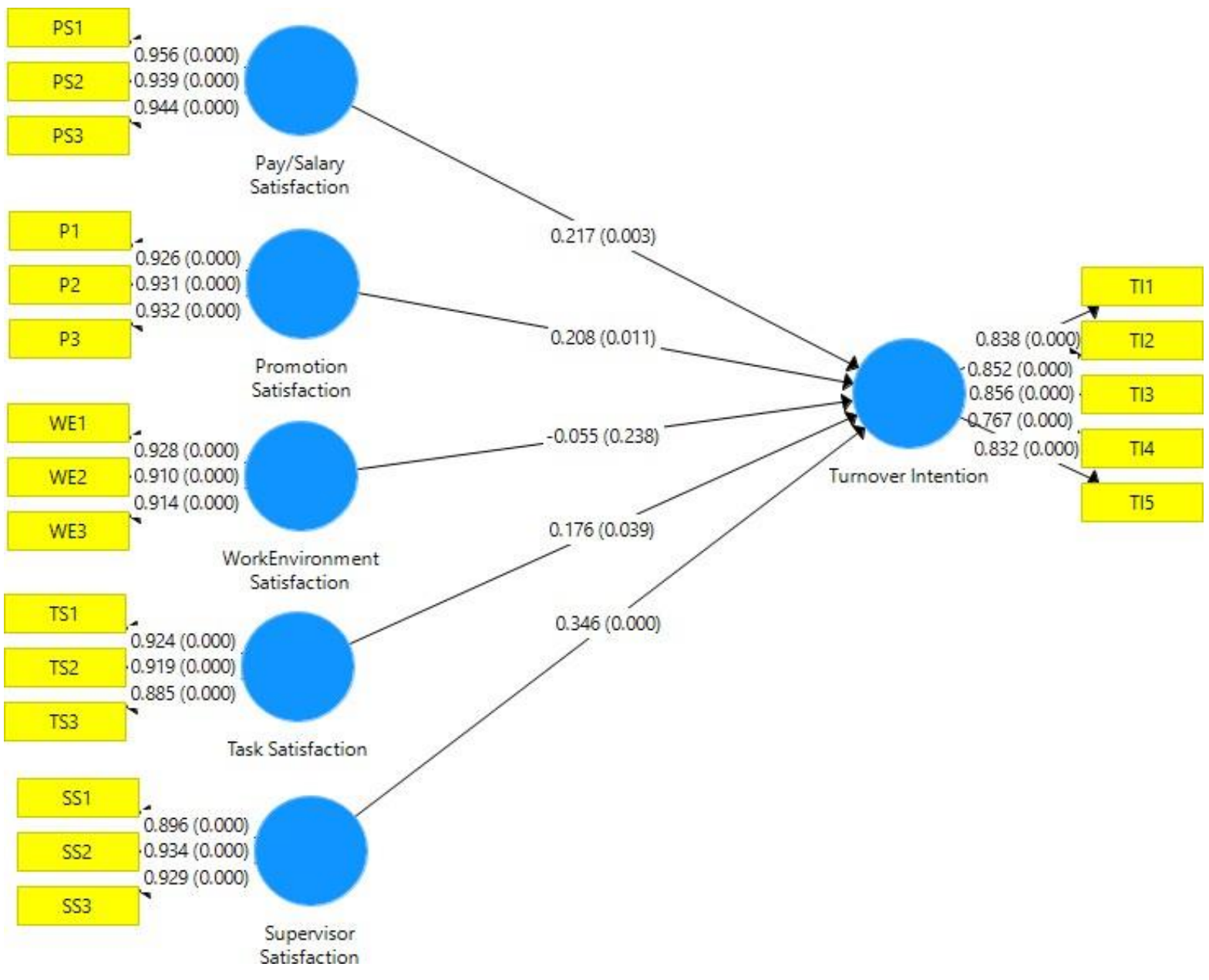


Path Coefficients

\begin{tabular}{|l|l|l|l|l|l|}
\hline & $\begin{array}{l}\text { Original } \\
\text { Sample } \\
(\mathbf{O})\end{array}$ & $\begin{array}{l}\text { Sample } \\
\text { Mean(M) }\end{array}$ & $\begin{array}{l}\text { Standard } \\
\text { deviation }\end{array}$ & $\begin{array}{l}\text { T Statistics } \\
(\mid \mathbf{O} / \text { STDEV|) }\end{array}$ & $\begin{array}{l}\text { P } \\
\text { Values }\end{array}$ \\
\hline $\begin{array}{l}\text { Pay/Salary Satisfaction- } \\
\text { > Turnover Intention }\end{array}$ & 0.217 & 0.209 & 3.013 & 3.013 & 0.003 \\
\hline $\begin{array}{l}\text { Promotion Satisfaction-> } \\
\text { Turnover Intention }\end{array}$ & 0.208 & 0.206 & 2.564 & 2.564 & 0.011 \\
\hline $\begin{array}{l}\text { Supervisor Satisfaction- } \\
\text { > Turnover Intention }\end{array}$ & 0.346 & 0.349 & 5.026 & 5.026 & 0.000 \\
\hline $\begin{array}{l}\text { Task Satisfaction -> } \\
\text { Turnover Intention }\end{array}$ & 0.176 & 0.181 & 2.073 & 2.073 & 0.039 \\
\hline $\begin{array}{l}\text { Work Environment } \\
\text { Satisfaction -> Turnover } \\
\text { Intention }\end{array}$ & -0.055 & -0.052 & 1.180 & 1.180 & 0.238 \\
\hline
\end{tabular}

The variation produced variable Pay/Salary Satisfaction is significant owing to the t-statistic $3.013>1.96$ and p-value $0.003<0.05$. Hence the Pay/Salary satisfaction is a significant with Turnover Intention. The variation produced variable Promotion Satisfaction is significant owing to the t-value $2.564>1.96$ and p-value $0.011<0.05$. Hence the Promotion satisfaction is a significant relationship with Turnover Intention. The variation produced variable Supervisor Satisfaction is significant owing to the t-statistic5.026> 1.96 and p-value $0.000<0.05$. Hence the Supervisor satisfaction is a significant relationship with Turnover Intention.

The variation produced variable Task Satisfaction is significant owing to the t-value $2.073>1.96$ and $p$-value $0.039<0.05$. Hence the Task satisfaction is a significant relationship with Turnover Intention. The variation produced variable Work Environment Satisfaction is significant owing to the t-value $1.180>1.96$ and p-value $0.238<0.05$. Hence the Work Environment Satisfaction does not have any significant relationship with Turnover Intention.

R Square:

\begin{tabular}{|l|l|l|}
\hline & R Square & R Square Adjusted \\
\hline Turnover Intention & 0.703 & 0.699 \\
\hline
\end{tabular}

$\mathrm{R}$-squared (R2) is a technical way for a dependent variable to calculate the variance ratio that is explained in multivariate analysis by an independent variable. The value of more than .50 in 
$\mathrm{R}$ square is strong and it means that the variables in the analysis are doing very well and the Model is fit.

\section{CONCLUSION}

The study was intended to investigate the impact of job satisfaction on employee turnover intention with in the banking sector of Pakistan in bank Al Habib. Globally, several literatures are available about Job satisfaction yet within the context of Pakistan, a limited portion of researches are available, especially, this is very first research conducted in bank Al Habib. Above literature review indicates that job satisfaction has impact on employee turnover intention, in this manner, this study result shows that the first-dimension salary satisfaction was found to have a significant negative relationship with turnover intention, which validates that if more salaries are offered to the employees, the job satisfaction level increases and turnover intention decreases. Similarly, the second dimension, promotion satisfaction was to also found to have a significantly negative relationship with turnover intention which asserts that higher promotion and career development opportunities reduce the employee turnover intention. Correspondingly, the third variable, work environment satisfaction has a negative significant relationship with turnover intention which demonstrates that the better co-worker relationships and better physical work environment characteristics reduces employees' turnover intention. Likewise, the fourth and fifth variables task satisfaction and supervision satisfaction, respectively, also validate a positive relationship with job satisfaction and a negative relationship with turnover intention.

\section{RECOMMENDATIONS}

Employees are the backbone of an organization. The retention of the employees is the primary objective of the banking sector. In the evolving business structures today, the human resource is considered as the main asset of an organization which contributes as the organizational human capital because they play a huge role in the organizational growth and development. This study findings aim to support the policy makers in the banking sector so that they can design appropriate policies for employee retention. It has also been evident that employee turnover significantly impacts an organization and place heavy monetary as well as resource costs for the organizations. The study highlighted the main domains of job satisfaction which include increase salaries, better task and work environments, better promotion opportunities and healthy relations with supervisors. All these dimensions were found to have statistically 
significant relationship with the dependent variable (turnover intention), accept of work environment which is found to be statistically insignificant. Thus, the findings assert that managers should devise appropriate polices which may increase employee's satisfaction level so as to retain them for a longer period of time. The future research studies can also choose a larger sample size which may generate more precise and effective result. The banking sector is emerging industry in Pakistan, and it is facing many challenges and problems. The banking sector requires tracking and monitoring certain aspects such as employee turnover issues. To generate the best result and to enhance the policies, it requires the practice multiple strategies and impact employee retention positively and to make empowered and competitive employees and it would become the likely organization within the national borders. The outcomes of the study show the independent variables positively impacting the employee retention in the workplace. The study recommends that the different cities provide the differentiated outcomes, and the researcher should choose the other bank or other kinds of sector (industrial, fashion). 


\section{REFERENCES}

Aftab, H. (2012). A Study of Job Satisfaction and IT's Impact on the Performance in the Banking Industry of Pakistan. International Journal of Business and Social Science, $3(19)$.

Ahmad, W. (2016). Impact of abusive supervision on job satisfaction and turnover intention: Role of power distance as a moderator. City University Research Journal, 6(1).

Iqbal, S., Hongyun, T., Akhtar, S., Ahmad, U., \& Ankomah, F. N. (2020). Impacts of Supervisor Support on Turnover Intentions: Mediating Role of Job Satisfaction. Asian Journal of Education and Social Studies, 1-9.

Khan, A. H., \& Aleem, M. (2014). Impact of job satisfaction on employee turnover: An empirical study of Autonomous Medical Institutions of Pakistan. Journal of International Studies, 7(1).

Khan, A. H., \& Aleem, M. (2014). Impact of job satisfaction on employee turnover: An empirical study of Autonomous Medical Institutions of Pakistan. Journal of International Studies, 7(1).

ALI, W. A. (2019). The mediating effect of job happiness on the raltionship between job satisfaction and employee performance and turnover intention. a case study on the oil and gas industry in the united arab emirates.

Ambrose, M. L. (2008). Individual Moral Develpoment and Ethical Climate- The influnce of Person Organization fit and JOb attitudes. Business Ethics , 323-333.

ASLAN1, D. H. (2019). "MEDIATING ROLE OF PERSON-ORGANIZATION FIT IN PERSON-JOB FIT'S EFFECT ON JOB SATISFACTION ". Journal of Economics

and Administrative Sciences , 275-284 .

Atif Anis, K.-u. R. (2011). Impact of Organization Commitment on The Job Satisfaction and Employee Retention in Pharmaceutical Industry. African Journal of Business Management, Vol. 5(17), pp. 7316-7324,. 
Babiak, P. (2015). Corporate psychopathy and abusive supervision : their influence on employees job satisfaction and turnover intentions.

Memon, M. A., Salleh, R., \& Baharom, M. N. R. (2017). The mediating role of work engagement between pay satisfaction and turnover intention. International Journal of Economics, Management and Accounting, 25(1), 43-69

Barry, R. a. (2001). Prinsip-Prinsip Manajemen Operasi: Operations Management, Salemba.

Bayona, J. A. (2020). "The Relationship between Knowledge Characteristics' Fit and Job Satisfaction and Job Performance: The Mediating Role of Work Engagement". Business Department, Pontificia Universidad Javeriana, 110221 Bogotá, Colombia; jaime.bayona@javeriana.edu.co .

Bibi, P. (2017). the impact of compensation and promotional oppurtunities on employee retention in academic institutions: the moderating role of work envirnoment .

Bilal Afsar, Y. F. (2016). Person-Organization Fit, Preceived organizational Support, and Organizational Citizenship Behavior: The role of Job Embeddedness. Human Resources in hospitality anf Tourism, 15(15), 252-278.

Busari, A. h. (2016). Analytical cognitive style Moderation on promotion and turnver intention.

Caldwell, D. F. (1990). Measuring Person Job Fit with a Profile . Comparsion Process .

Applied Psychology .

Carmeli, A. M. (2006). Self-leadership skills and innovative behavior at work.International Journal of Manpower.

Chang-qin Lu, H.-J. W. (2014). Does work engagement increase person-job fit? The role of Job crafting and job insecurity . Vocational Behavior, 84(2), 142-152. 
Chen, P. (2019). "The relationship between person-organization fit and job satisfaction". 1Southwestern University of Finance and Economics, Sichuan Ctiy, China, 2Lancaster University, Lancaster, UK, and 3Manchester University, Manchester, UK

Chhabra, B. (2015). Person-Job fit: mediating role of job satisfaction and organization commitment . Indian journal of industrial relations .

Chhabra, b. (2018). Person Job Fit: Mediating Role of Job Satisfaction and Organization Commitment.

Chin, C. L. (2018). The influence of job satisfaction on employee turnover intention in the manufacturing industry of Malaysia. Journal of Arts \& Social Sciences, 1(2), 53-63.

Chunjiang, Y. (2011). The Effect of Person Organization Fit on Job satisfaction and Trunover Intention .

Datta.B. Pawase, D. P. (2013). "Role of P-E fit on Job Satisfaction of Medical Representatives". International Journal of Engineering Research and Applications (IJERA), 19-22 .

David. (2001). A comparative analysis among public versus private sector.

Dawley, D. D. (2012). Staying Put Off-the-Job Embeddedness as a Moderator of the Relationship Between On-the-job Embeddedness and Turnover Intentions. Journal of Leadership \& Organizational Studies.

Dubey, R. C. (2016). Relationship between Person Organization and Job satisfaction: Mediating Role of Need Satisfaction. International Journal of Education and Management, 170-174. 
Ekhsan, M. (2019). The influence job satisfaction and organizational commitment on employee turnover intention. Journal of Business, Management, and Accounting, 1(1), 4855.

Farooquia, M. S., \& Nagendrab, D. A. (2014). "The Impact of Person organization Fit on Job Satisfaction and Performance of the Employees". Symbiosis Institute of Management Studies Annual Research Conference (SIMSARC13), 122 - 129.

Fiske, C. a. (1959). Wikipedia the free encyclopedia. Retrieved from Wikipedia: https://en.wikipedia.org/wiki/Discriminant_validity

Fornell, C. \&. ((1981)). Structural equation models with unobservable variables and measurement error:. Algebra and statistics., 382-388.

Garg, G. S. (2012). An empiracal study determinants of job satisfaction and effect on employee turnover in Hotel of Kuala Lampur.

Ghosh, P. (2015). Exploring the moderating role of context satisfaction between job characterstics and turnover intention.

Gul, H. U. (2018). Does the effect of power distance moderate the relation between person environment fit and job satisfaction leading to job performance? Evidence from Afghanistan and Pakistan,. Future Business Journal,, 4(1): 68-83.

Gunawan, R. (2017). the effect of work environment, leadership style, and organizational culture towards job satisfaction and its implication towards employee performance in parador hotels and resorts, Indonesia.

Hair, J. F. (2006). Multivariate data analysis. Uppersaddle River.

Hair, J. F., Matthews, L. M., Matthews, R. M., \& Sarstedt, M. (2017). PLS-SEM or CB- SEM: updated guidelines on which method to use. Int. J. Multivariate Data Analysis, 107123.

Henseler, J. (2010). On the convergence of the partial least squares path modeling algorithm2E. Computational statistics,, 25(1), 107-120. 
Henseler, J. H. ((2016).). . Using PLS path modeling in new technology research: updated guidelines. . Industrial management \& data systems.

Herry. (2001). a dictionary of human resource managment, oxford university press , NEW YORK.

Huang, S., Chen, Z., Liu, H., \& Zhou, L. (2017). Job satisfaction and turnover intention in China. Chinese Management Studies.

Hung, L.-M. (2018). The moderating effect of salary satisfaction and work pressure on the organizational climate, organizational comitment to turnover intention.

Index, J. D. (2009). Bowling Green State University. Retrieved from.

Shah, N. H., \& Jumani, N. B. (2015). Relationship of job satisfaction and turnover intention of private secondary school teachers. Mediterranean Journal of Social Sciences, 6(4), 313313.

Kalidass, A., \& Bahron, A. (2015). The relationship between perceived supervisor support, perceived organizational support, organizational commitment and employee turnover intention. International Journal of Business Administration, 6(5), 82.

Kee, D. M. (2015). perceived fairness of performance appraisal, promotional oppurtunity and nurses turnover intention: the role of organizational commitment.

Khan. (2014). Organizational cynicism and employee turnover intention: Evidence from banking sector in Pakistan .

Koh, W. L. (2000). An Experimental Analysis of the Impact of Pay for Performance on Employee Satisfaction, Research and practice in human resource managemnt.

Kristof-Brown, A. L. (2015). Consequences Of Individuals'fit At Work: A Meta-Analysis Of Person-Job, Person-Organization, Person-Group, And Person-Supervisor Fit,. Personnel Psychology,, 58(2): 281-342. . 
Lawler, E. (1968). A correlational-causal analysis of the relationship between expectancy attitudes and job performance .

Lee, X. (2017). the influence factors of job satisfaction and its relationship with turnover intention.

Locke, E. (1976). The nature and causes of job satisfaction”, in Dunnette, M. (Ed.), The Handbook of Industrial and Organisational Psychology, Rand McNally, Chicago.

Malik, E. M. (2010). Job Satisfaction and Organizational Commitment of University tachers in public sector of pakistan.

Mao, C. (2014). "The Impact of Person-Job Fit on Job Satisfaction: The Mediator Role of Self Efficacy. Springer Science +business Media Dordrecht .

Marginson, S. (2003). Quality of higher education. Australian Journal of Education. Monash University, Australia.

Maslow, A. (1943). "A theory of human motivation”,.

Masood Hassan, T. S. (2019). Employes tunrover in Public sector banks of Pakistan . McGregor, D. (1960/2006). The Human Side of Enterprise, annotated edition, McGraw-Hill.

Mete, E. S. (2016). The relationship between Organizational Commitment, Organizational identification person organization fit and job satisfaction. International Review of Management of and Business Research , 2306-9007.

Min-Ji Je, Y. G. (2010). Effects of Person Organziation Fit Fit and Person Job Fit on Occupational Commitment, Organizational Commitment and Turnover intention of Cooks. Culinary Science and Hospitality Reserach , 16(5),50-63.

Mohammed Saud Miraa*, Y. V. (2019). The effect of HRM practices and employees' job satisfaction on employee performance. University of Multi Media, Cyberjaya, Malaysia , 771-786. 
Mosammod Mahamuda Parvin, M. M. (2011). FACTORS AFFECTING EMPLOYEE JOB SATISFACTION OF PHARMACEUTICAL SECTOR. Australian Journal of Business and Management Research, Vol.1 No.9 [113-123] .

Muthuvelooa, S. A. (2020). "Human resource management practices and person-organization fit towards nurses' job satisfac- tion . Graduate School of Business, Universiti Sains Malaysia, 11800 Penang, Malaysia .

Naval. (2004). Sectorial comparison of factors influencing job satisfaction in indian banking sector.

Nawaz, M. S. (2015). the relationship between human resource devolopmet factors, career growth and turnover intention.

OWHONDAH, E. I., Onuoha, B. C., \& AKHIGBE, D. (2016). Promotion and Turnover Intentions in Selected Oil Firms in Rivers State. International Journal of Advanced Academic Research, 2(8), 76-84.

Prinsa. (2016). perencanaan dan pengemdangan sumber daya manusia . bandung: alfabeta.

Wang, Q., Li, R., \& Wang, A. (2019, May). The Impact of Promotion Justice on Occupational Health and Turnover Intention. In 2019 International Conference on Management, Education Technology and Economics (ICMETE 2019). Atlantis Press.

Rajper, Z. A. (2020). The Impact of Person Job Fit and Person Organization Fit on Employee JOb Performance: A study among Employee of Services Sector. Abasyn University Journal Social Sciences, 54-65.

Ramesh. (2012). factors afecting turnover intention of employees in banking sector

,international journal of academics business and social sciences.

Ramly, M. (2019). the effect of work environment, stress, and job satisfaction on employee turnover intention. 
Raosoft. (2020, dec 15). Sample size calculator. Retrieved from Raosoft: http://www.raosoft.com/samplesize.html

Raosoft. (2020, Dec 15). Sample size calculator. Retrieved from Raosoft: http://www.raosoft.com/samplesize.html

Saeed, I., Waseem, M., Sikander, S., \& Rizwan, M. (2014). The relationship of turnover intention with job satisfaction, job performance, leader member exchange, emotional intelligence and organizational commitment. International Journal of Learning and Development, 4(2), 242-256.

Salleh, R., Nair, M. S., \& Harun, H. (2012). Job satisfaction, organizational commitment, and turnover intention: A case study on employees of a retail company in Malaysia. International Journal of Economics and Management Engineering, 6(12), 3429-3436.

Selamat, S., \& Heryanto, H. (2019). Affecting Factors In Employee Performance Koto Baru Sub-District, Dharmasraya District. Archives of Business Research, 7(7), 142-154.

Senevirathne. (2020). the relationship between coo-workers support, supervisor support, organizational support and employee turnover intention.

Wan, Q., Li, Z., Zhou, W., \& Shang, S. (2018). Effects of work environment and job characteristics on the turnover intention of experienced nurses: The mediating role of work engagement. Journal of Advanced Nursing, 74(6), 1332-1341.

Sharon Ruvimbo Terera, H. N. (2014). The Impact of Rewards on Job Satisfaction and Employee Retention . Mediterranean Journal of Social Sciences, Vol 5 No 1 E-ISSN 2039-2117.

Silverthrone, C. (2004). The impact of Organization culture and person-organization fit on organizational commitment and job satisfaction in Taiwan. The leadership and

Organization Develpoment journal www.emeraldinsight.com/researchregister, 0143- 7739.

Soelton, M., \& Atnani, M. (2018). How Work Environment, Work Satisfaction, Work Stress on the Turnover Intention Affect University Management. Jurnal Manajemen Bisnis Indonesia, 5, 439-448. 
Swe, K. T. H., \& Lu, L. H. (2019). The enhancement of employee engagement to reduce employee turnover intention and improve employee job satisfaction: an action research on Mirac Company in Yangon, Myanmar. ABAC ODI Journal Vision. Action. Outcome, 6(1), 123.

Aguenza, B. B., \& Som, A. P. M. (2018). Motivational factors of employee retention and engagement in organizations. International Journal of Advances in Agriculture Sciences.

Huning, T. M., \& Thomson, N. F. (2010). The impact of performance attributions and job satisfaction on turnover intentions. In Allied Academies International Conference. Academy of Organizational Culture, Communications and Conflict. Proceedings (Vol. 15, No. 1, p. 27). Jordan Whitney Enterprises, Inc.

Yi- Chang Lin, C. Y.-C. (2014). The Effect of Positive affect Person-Job Fit and Well-being on Job performance. Social Behavior and Personalithy: an International Journal, 42(9),1537-1547.

Wiliyanto, I. T., Sudiarditha, I. K., \& Yohana, C. (2020). Influence of Work Environment Toward Turnover Intention with Motivation and Job Satisfaction as Intervening Variables in PT. TSA. International Journal on Advanced Science, Education, and Religion, 3(1), 11-21.

Samad, S., \& Yusuf, S. Y. M. (2012). The role of organizational commitment in mediating the relationship between job satisfaction and turnover intention. European Journal of Social Sciences, 30(1), 125-135 